\title{
REMOVAL OF C.I. BASIC YELLOW 2 FROM AQUEOUS SOLUTION BY ADSORPTION ONTO GRANULAR ACTIVATED CARBON USING AN ON-LINE SPECTROPHOTOMETRIC ANALYSIS SYSTEM: KINETIC AND EQUILIBRIUM STUDY
}

\author{
S. ABER* \\ F. HADDADI ESFAHLAN
}

\author{
Research Laboratory of Environment Protection Technology \\ Department of Applied Chemistry \\ Faculty of Chemistry, University of Tabriz, Tabriz, Iran
}

Received: $16 / 03 / 10$

Accepted: 09/08/11 *to whom all correspondence should be addressed: e-mail: soheil_aber@yahoo.com

\begin{abstract}
The adsorption of Basic yellow 2 (BY2), from aqueous solutions onto Granular activated carbon (GAC) and its adsorption kinetics at different concentrations, GAC masses, initial $\mathrm{pH}$ values and temperatures were studied. The adsorption process was followed by an on-line spectrophotometric analysis system, which consisted of UV-spectrophotometer, a designed spectrophotometric cell, peristaltic pump and a glassy reactor. The effect of initial dye concentration, mass of GAC, initial pH and temperature on adsorption was studied over $60 \mathrm{~min}$ adsorption period. The results showed that at first the removal percent of BY2 increases with the increase in initial concentration, then the trend is reversed. The results also showed that removal percent of $\mathrm{BY} 2$ at $\mathrm{pH}_{\mathrm{i}}$ around 7 is more than acidic $\mathrm{pH}_{\mathrm{i}}$. Also the removal percent of BY2 increases with the increase in mass of GAC and temperature. For kinetic study, the obtained data were treated according to various kinetic models. The results showed that first order kinetic model is fitted to experimental data better than second order and intraparticle diffusion models. The Freundlich, Langmuir, Redlich-Peterson and BET adsorption models were applied to describe the equilibrium isotherms. Type 1 Langmuir isotherm and non-linear Redlich-Peterson isotherm seemed to be the best-fitting models for the experimental results with similar values of coefficient of determination.
\end{abstract}

KEYWORDS: Adsorption, Basic yellow 2, Decolorization, GAC, Removal, Treatment.

\section{INTRODUCTION}

Basic yellow 2 (4,4-dimethylaminobenzophenonimide) and its hydrochloride salt are used in the colouring of paper, textiles and leather, also as food dye (Martelli et al., 1998). International Agency for Research on Cancer included Basic yellow 2 among chemicals for which there is sufficient evidence of carcinogenicity in experimental animals (IARC, 1987) due to its bio-transformation to reactive species in target organs of both rats and humans (Martelli et al., 1998). Basic yellow 2 (BY2), a yellow dye, is commonly used in paper mills, textile mills, leather and carpet industry. Dyes are highly persistent as the manufacturers always go for the most stable dye. Most of the dyes bearing wastewaters have high $C O D$ to $B O D$ ratio and they offer considerable resistance for their biodegradation due to thermo- and photo-stability of the dyes (Nassar and Magdy, 1997). In fact, the dyes are not easily biodegradable and often are not fully removed in conventional biological plants. Therefore, a tertiary refining process is required for a complete decolorization in order to obtain an effluent of high quality suitable for reuse in the same dye house plant. Among the advanced chemical or physical treatments, adsorption is considered more effective and less expensive than other technologies such as ozone or electrochemical oxidation, membrane separation, etc. Activated carbon is the most used adsorbent owing its high capacity. We have developed a simple, cost effective BY2 removal technique using technical grade Granular activated carbon (GAC). Most of the 
adsorption studies from aqueous solutions involve the measurement of concentration of the adsorbate as a function of various parameters. Therefore the concentration of adsorbate should be followed by a suitable, fast responding and preferably non-destructive method. On-line measurement systems like this work can produce a lot of valuable data in short time intervals which are necessary for precise kinetic study and reduce the errors from sampling procedure. This method also reduces the amount of chemicals in a series of experiments (Ayranci and Hoda, 2004). The aim of the present work is to study the adsorption of Basic yellow 2 (Table 1), on GAC under different conditions by an on-line spectrophotometric analysis system, which consisted of a UVspectrophotometer, a spectrophotometric cell, peristaltic pump and a glassy reactor, base on our previous work (Daneshvar et al., 2007).

\section{EXPERIMENTAL}

\subsection{Materials}

The industrial granular activated carbon used in the present work was obtained from typical market and its properties such as the point of zero charge (PZC) and iodine number (Mustafa et al., 2002 and Matsumura et al., 1997) are determined equal to 3 and $1330.24 \mathrm{mg} \mathrm{g}^{-1}$, respectively (with cylindrical shape and average diameter and length of 4 and $7 \mathrm{~mm}$, respectively). The Basic yellow 2 , was obtained from Aldrich company and used without further purification. Distilled water was used in all adsorption experiments.

\subsection{Methods}

On-line spectrophotometric analysis system, which consisted of a UV-spectrophotometer (PerkinElmer 550 SE, Germany), a spectrophotometric cell, peristaltic pump (Eyela, Mob-1, Japan), water bath (Grant Instruments SB3, England) with temperature controller (Jumo, ITron 04, Germany) and a glassy reactor, is shown in Figure 1. The UV-Vis spectrophotometer was used for optical absorbance measurements. A special glassy reactor cell was designed to carry out the adsorption experiments. The glassy reactor contains a tube as inlet of Argon gas, which mixes the contents of reactor and eliminates dissolved $\mathrm{CO}_{2}$ and air (Ayranci and Hoda, 2005). The other tube allows circulating the solution. One thermometer has been attached to monitor the temperature of solution and one hatch is as gas outlet.

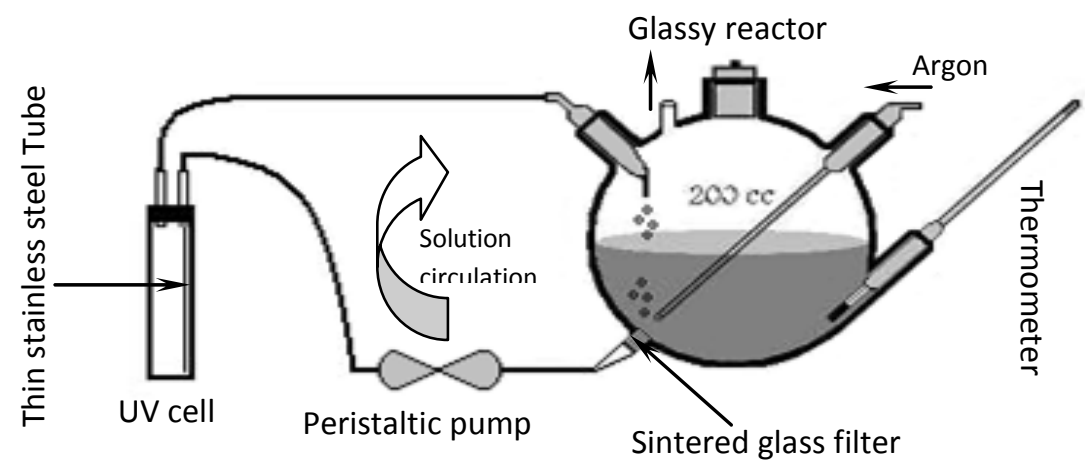

Figure 1. Schematic of on-line analysis system

The $\mathrm{pH}$ values were adjusted at desired level using dilute $\mathrm{NaOH}$ and $\mathrm{H}_{2} \mathrm{SO}_{4}$ and measured with $\mathrm{pH}$ meter (Philips PW 9422). All GAC samples were weighted $( \pm 0.0001 \mathrm{~g})$ with balance (Shimadzu, Japan). All absorbance measurements were done at $434 \mathrm{~nm}$, because the maximum absorbance wavelength of $\mathrm{BY} 2$ at different $\mathrm{pH}$ values is 434 .

Absorbance versus concentration data for standard solutions of BY2 were treated by linear regression analysis with $R^{2}=0.999$ to plot calibration line and to convert absorbance data to concentration. Adsorption measurements were repeated on duplicate. The efficiency of color removal was expressed as the percentage of removal of dye concentration (Eq. 1), where $C_{o}$ is the initial concentration of BY2 (ppm) and $C$ is the concentration of dye at time $t$ (min). 
Color Removal $(\%)=\frac{C_{\circ}-C}{C_{\circ}} \times 100$

\subsection{Determination of adsorption isotherms}

The adsorption isotherms of BY2 on GAC were determined on the basis of batch analysis. Different amounts of GAC were allowed to equilibrate with constant initial concentrations of dye solution $\left(\mathrm{C}_{0}=200 \mathrm{ppm}\right)$. The solutions were allowed to stay 1 week in experimental condition then the equilibrium concentration of dye solutions were measured spectrophotometrically. The amount of dye adsorbed per mass unit of GAC in equilibrium condition, $q_{e}$, was calculated by Eq. 2:

$q_{e}=V \frac{C_{0}-C_{e}}{m}$

where $V$ is the volume of dye solution in $\mathrm{L}, C_{0}$ and $C_{e}$ are the initial and equilibrium concentrations, respectively, of the dye solutions in ppm and $m$ is the mass of the GAC in $g$.

Table 1. Chemical structure, molecular weight and other names of BY2

\section{Basic \\ Dye}

Basic

yellow 2
Structure

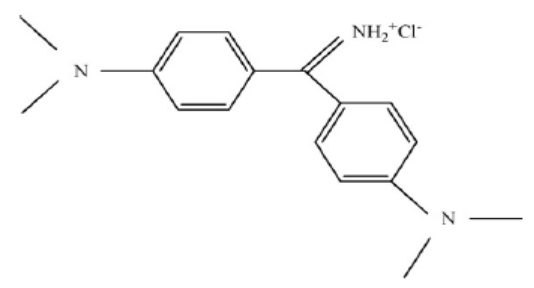

Molecular weight Other $\left(\mathrm{g} \mathrm{mol}^{-1}\right)$ name

\subsection{Kinetics of adsorption}

To study the kinetics of adsorption of BY2 on GAC, the adsorption experiments in different initial dye concentrations, initial $\mathrm{pH}$, temperatures and masses of GAC were conducted. Absorbance data of BY2 solution were obtained in $1 \mathrm{~min}$ intervals from 0 to $30 \mathrm{~min}$ and in five-minute intervals from 30 to 60 min during the adsorption process, then absorbance data were converted into concentration using the corresponding calibration plots. Three kinetic models were applied to fit them to experimental data. These models include intraparticle diffusion (Ayranci and Hoda, 2005), which can be formulated as:

$q_{t}=k_{i} t^{\frac{1}{2}}$

first order model with following equation:

$\ln C-\ln C_{0}=-k_{1} t$

and second order model which is in the form of:

$$
\frac{1}{C}-\frac{1}{C_{0}}=k_{2} t
$$

where $\mathrm{q}_{\mathrm{t}}$ is the amount of adsorbate adsorbed at any time per unit mass of adsorbent $\left(\mathrm{mg} \mathrm{g}^{-1}\right), \mathrm{C}_{0}$ is initial concentration of adsorbate in the solution (ppm), $C$ is the concentration of adsorbate in the solution at any time $(\mathrm{ppm}), \mathrm{t}$ is time $(\mathrm{min})$ and $\mathrm{k}_{\mathrm{i}}\left(\mathrm{mg} \mathrm{g}^{-1} \mathrm{~min}^{-1 / 2}\right), \mathrm{k}_{1}\left(\mathrm{~min}^{-1}\right)$ and $\mathrm{k}_{2}\left(\mathrm{~min}^{-1} \mathrm{ppm}^{-2}\right)$ are rate constants for intraparticle diffusion, first order and second order models, respectively. $q_{t}$ is obtained from Eq. 2. The applicability of each model was studied by drawing linear plot of $q_{t}$ versus $t^{1 / 2}$ for intraparticle diffusion, $\left(\ln C-\ln C_{0}\right)$ versus $t$ for first order and $\left(\frac{1}{C}-\frac{1}{C_{0}}\right)$ versus $t$ for second order models. The rate constants of $k_{i}, k_{1}$ and $k_{2}$ obtained from the slopes of corresponding linear plots and correlation coefficients, $r$, were calculated. 


\subsection{Adsorption isotherms of Basic yellow 2}

In order to assess the potential adsorption capacity of the GAC toward the Basic yellow 2, its adsorption isotherms at $25^{\circ} \mathrm{C}$ were derived on the basis of batch analysis as described in section 2.3. The isotherm data were treated according to the well known Freundlich, Langmuir, RedlichPeterson and BET isotherm models. In the Langmuir theory, the basic assumption is that the sorption takes place at specific homogenous sites on the surface of the adsorbent. This equation can be written as follows (Benefield et al., 1982; Alley, 2000; Woodard, 2001):

$$
q_{e}=\frac{q_{m} b C_{e}}{1+b C_{e}}
$$

Where $q_{e}$ is the amount of dye adsorbed onto unit mass of GAC at equilibrium condition $(\mathrm{mg} / \mathrm{g}), C_{e}$ is the equilibrium concentration of dye solution (ppm), $b$ is equilibrium constant and $\mathrm{q}_{\mathrm{m}}$ is the maximum adsorption capacity $\left(\mathrm{mg} \mathrm{g}^{-1}\right)$. The linear forms of Eq. (6) are Eq. 7 (Langmuir type 1) and Eq. 8 (Langmuir type 2), respectively:

$$
\frac{C_{e}}{q_{e}}=\frac{1}{b q_{m}}+\frac{C_{e}}{q_{m}}
$$

and

$$
\frac{1}{q_{e}}=\left(\frac{1}{b q_{m}}\right) \frac{1}{C_{e}}+\frac{1}{q_{m}}
$$

Langmuir constants, $\mathrm{q}_{\mathrm{m}}$ and $b$, can be calculated from the plot between $\frac{C_{e}}{q_{e}}$ versus $C_{e}$ and $\frac{1}{q_{e}}$ versus $\frac{1}{C_{e}}$ for types 1 and 2 , respectively. The essential characteristic of the Langmuir isotherm can be expressed by the dimensionless constant called equilibrium parameter, $R_{L}$, defined as:

$$
R_{L}=\frac{1}{1+b C_{0}}
$$

where $b\left(\mathrm{~L} \mathrm{mg}^{-1}\right)$ is the Langmuir constant and $\mathrm{C}_{0}\left(\mathrm{mg} \mathrm{L}^{-1}\right)$ the initial concentration. Isotherm is considered to be unfavorable, linear, favorable or irreversible depending on the value of $R_{L}$ (Ayranci and Hoda, 2005). Since the obtained value $R_{L}$ is in the range of zero and one, the adsorption is favorable (Daneshvar et al., 2002). The Freundlich isotherm is derived by assuming a heterogeneous surface with a non-uniform distribution of heat of adsorption over the surface. Freundlich isotherm is expressed by Benefield et al. (1982), Alley (2000) and Woodard (2001) as:

$$
q_{e}=K_{f} C_{e}^{\frac{1}{n}}
$$

where $K_{f}$ is adsorption capacity at unit concentration and $1 / n$ is adsorption intensity and they can be calculated from the plot of $\ln q_{e}$ versus $\ln C_{e}$. 1/n values indicate the type of isotherm to be irreversible $(1 / n=0)$, favorable $(0<1 / n<1)$, unfavorable $(1 / n>1)$ (Alley, 2000). Eq. (10) can be rearranged to a linear form:

$$
\ln q_{e}=\ln K_{f}+\frac{1}{n} \ln C_{e}
$$

The Redlich-Peterson isotherm can be written as follows (Benefield et al., 1982 and Alley, 2000 and Woodard, 2001):

$$
q_{e}=\frac{A C_{e}}{1+B C_{e}^{g}}
$$

The Redlich-Peterson isotherm constants can be predicted by treating the experimental data with equation 12 using mathematical software. Also, the BET isotherm can be represented as Eq. (13) (Benefield et al., 1982; Alley, 2000; Woodard, 2001): 


$$
q_{e}=\frac{q_{m} K_{b} C_{e}}{\left(C_{o}-C_{e}\right)\left[1+\left(K_{b}-1\right) \frac{C_{e}}{C_{o}}\right]}
$$

where $\mathrm{K}_{\mathrm{b}}$ is a constant expresses the energy of interaction with the surface. The linear form of Eq.

(13) can be written as follows:

$$
\frac{\frac{C_{e}}{C_{o}}}{q_{e}\left(1-\frac{C_{e}}{C_{o}}\right)}=\frac{1}{K_{b} q_{m}}+\frac{K_{b}-1}{K_{b} q_{m}} \frac{C_{e}}{C_{o}}
$$

BET constants, $K_{b}$ and $q_{m}$ values can be calculated from the plot between $\frac{\frac{C_{e}}{C_{o}}}{q_{e}\left(1-\frac{C_{e}}{C_{o}}\right)}$ versus $\frac{C_{e}}{C_{o}}$.

\section{RESULTS AND DISCUSSION}

\subsection{Effect of initial dye concentration $\left(C_{0}\right)$}

In order to make a comparative study for adsorption of BY2 in its different initial concentrations, the weight of $\mathrm{GAC}(\mathrm{m}=1 \mathrm{~g})$, initial $\mathrm{pH}\left(\mathrm{pH}_{\mathrm{i}}=7\right)$ and temperature $\left(\mathrm{T}=25{ }^{\circ} \mathrm{C}\right)$ were kept the same in all adsorption experiments. The change in BY2 removal with time during the adsorption on GAC for different initial concentrations is shown in Figure 2. From the figure, it is evident that the removal percent of BY2 increases for initial dye concentrations from $10 \mathrm{ppm}$ to $15 \mathrm{ppm}$ and then decreases from $15 \mathrm{ppm}$ to $25 \mathrm{ppm}$. This observation is related to constant number of adsorbent sites while the number of dye molecules increases, so to some extent with increasing the initial dye concentration the rise in amount of adsorbed dye is more than rise in remained one and the removal percent increases. After that, rise in adsorbed amount of dye is lower than rise in remained dye, so removal percent of dye decreases. A behavior similar to this has also been observed by Eren and Acar (Eren and Acar, 2006) for adsorption of Reactive Black 5 from aqueous solution.

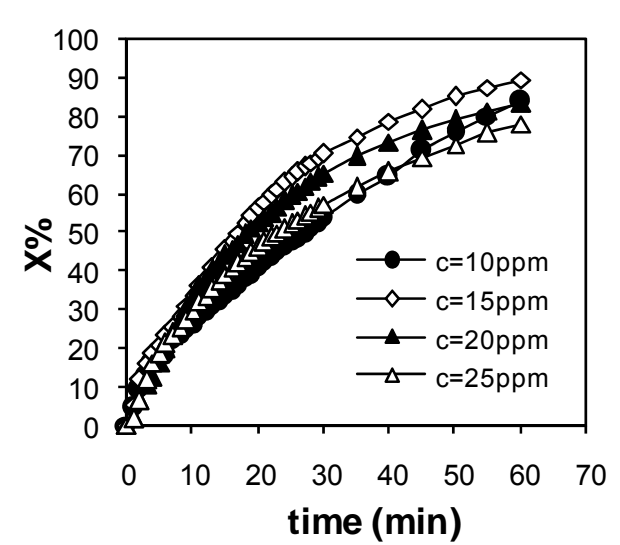

Figure 2. Effect of initial dye concentration on removal of BY2 at: $\mathrm{m}=1 \mathrm{~g}, \mathrm{pH}_{\mathrm{i}}=7$ and $\mathrm{T}=25^{\circ} \mathrm{C}$

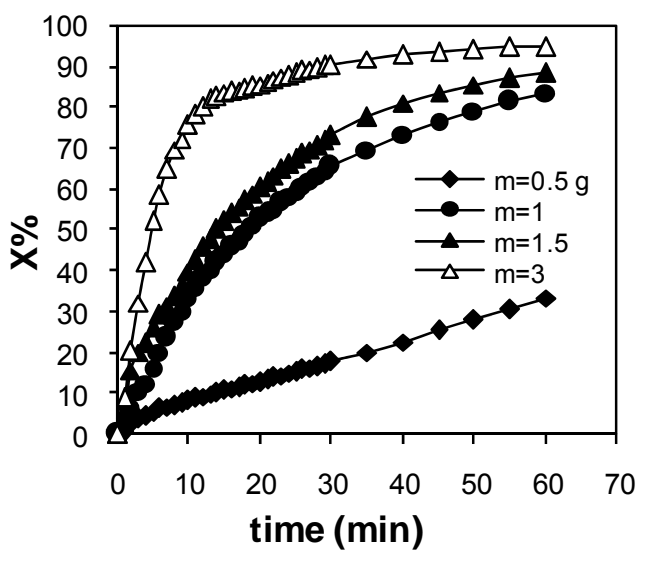

Figure 3. Effect of amount of GAC on removal of BY2 at: $\mathrm{C}_{\mathrm{o}}=20 \mathrm{ppm}, \mathrm{pH}_{\mathrm{i}}=7$ and $\mathrm{T}=25^{\circ} \mathrm{C}$

\subsection{Effect of adsorbent dosage (m)}

In order to make a comparative study for adsorption of BY2 in different amounts of GAC, the initial concentration of dye $\left(\mathrm{C}_{0}=20 \mathrm{ppm}\right), \mathrm{pH}_{\mathrm{i}}$ (equal to 7 ) and temperature $\left(\mathrm{T}=25^{\circ} \mathrm{C}\right.$ ) were kept the same in all adsorption experiments. It was observed that the removal percent of the dye increased with increase in adsorbent mass (Figure 3). An increase in the adsorption with the adsorbent dosage can be attributed to greater surface area and the availability of more adsorption sites while the number of adsorbate molecules is constant. 


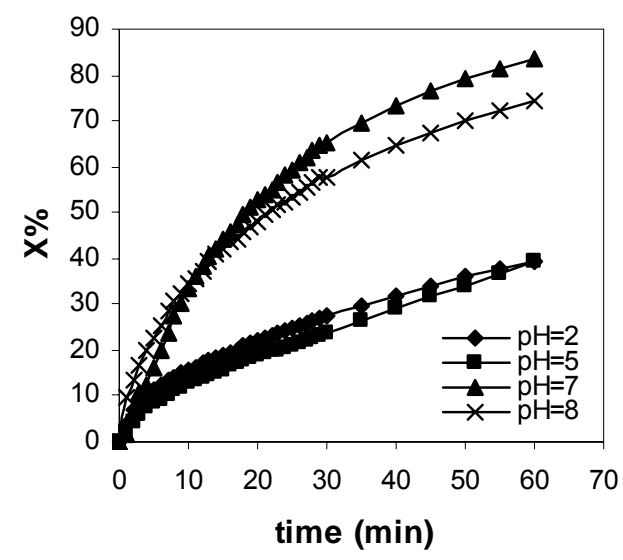

Figure 4. Effect of initial $\mathrm{pH}$ on removal of BY2 at: $\mathrm{m}=1 \mathrm{~g}, \mathrm{C}_{\mathrm{o}}=20 \mathrm{ppm}$ and $\mathrm{T}=25^{\circ} \mathrm{C}$

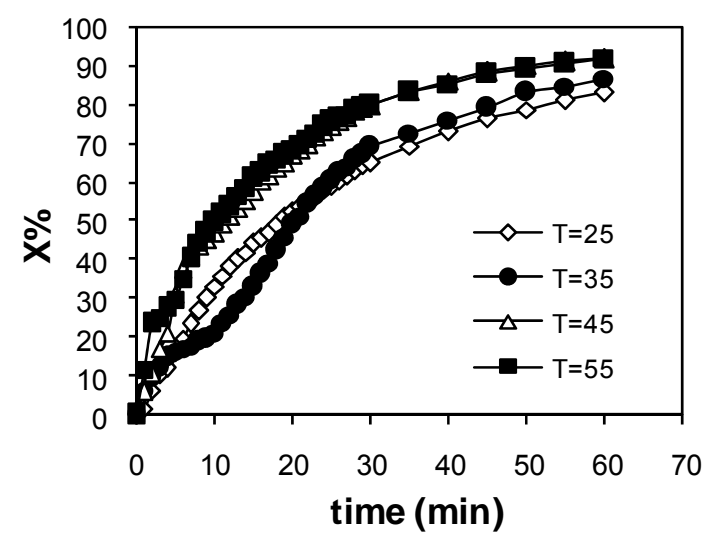

Figure 5. Effect of temperature on removal of BY2 at: $\mathrm{m}=1 \mathrm{~g}, \mathrm{C}_{\mathrm{o}}=20 \mathrm{ppm}, \mathrm{pH}_{\mathrm{i}}=7$

\subsection{Effect of initial pH}

In order to study the effect of different values of initial $\mathrm{pH}$ on the adsorption of BY2, the initial concentration of dye $\left(\mathrm{C}_{0}=20 \mathrm{ppm}\right)$, the weight of $\mathrm{GAC}(\mathrm{m}=1 \mathrm{~g})$ and temperature $\left(\mathrm{T}=25^{\circ} \mathrm{C}\right)$ were kept the same in all adsorption experiments. The amount of electrostatic charges on ionized dye molecules is primarily controlled by the $\mathrm{pH}$ of medium. The amount of dye adsorbed or rate of adsorption tends to vary with $\mathrm{pH}$ of aqueous medium. The changes in dye removal with time during the adsorption on the GAC for different $\mathrm{pH}$ values are shown in Figure 4. It shows that the adsorption of the dye at $\mathrm{pH}$ about 7 was more than acidic $\mathrm{pH}$. Several reasons may affect on the adsorption of dye by the adsorbent relative to $\mathrm{pH}$. The surface of the adsorbent contains large number of reactive sites. At lower $\mathrm{pH}$, the surface of the GAC is positively charged and the dye is present as neutral molecules and there is not any significant attraction between surface of adsorbent and the dye. Thus, a low amount of dye is adsorbed. At higher $\mathrm{pH}$ values, the surface of the GAC gets negatively charged, which enhances the interaction of positively charged dye cations with the surface of GAC through the electrostatic forces of attraction (Mall et al., 2007).

\subsection{Effect of temperature ( $T$ )}

In order to study the effect of temperature on adsorption of BY2, the initial concentration of dye $\left(\mathrm{C}_{0}=\right.$ $20 \mathrm{ppm}$ ), the weight of $\mathrm{GAC}(\mathrm{m}=1 \mathrm{~g})$ and $\mathrm{pH}_{\mathrm{i}}$ (equal to 7) were kept the same in all adsorption experiments. The change in dye concentration with time during the adsorption process at each temperature is shown in Figure 5. From the figure, it is obvious that the removal percent of dye increases with increase in temperature from $25{ }^{\circ} \mathrm{C}$ to $55{ }^{\circ} \mathrm{C}$. A similar behavior has also been observed by Karagozoglu et al. (2007) for adsorption of Astrazon Blue FGRL onto sepiolite, fly ash and apricot shell activated carbon. The rise of adsorption with temperature could be due to the enlargement of the pore sizes of adsorbent particles at elevated temperatures (Namasivayam and Yamuna, 1995). Also, effective interaction between adsorbate molecules and adsorbent increases with increase in temperature. This also indicates that the adsorption process is more chemical than physical in its nature because physical adsorption decreases in high temperatures.

\subsection{Kinetics of adsorption}

The rate constants of $\mathrm{k}_{\mathrm{i}}, \mathrm{k}_{1}$ and $\mathrm{k}_{2}$ obtained from the slopes of corresponding linear plots, and corresponding correlation coefficients, $r$, are given in Tables 2, 3, 4 at different initial dye concentrations, GAC masses and initial pH values. Considering 0.99 as criteria, first order and intraparticle diffusion models better fit the experimental data for the effect of initial dye concentration, first order and second order models better fit for the effect of adsorbent dosage and all three models similarly can simulate the effect of $\mathrm{pH}$ values. 
Table 2. Rate constants and correlation coefficients from treatment of adsorption data to three kinetic models in different initial dye concentrations

\begin{tabular}{|c|c|c|c|c|c|c|}
\hline \multirow{3}{*}{$\begin{array}{c}\text { Initial dye } \\
\text { concentration }\end{array}$} & \multicolumn{6}{|c|}{ Kinetic model } \\
\hline & \multicolumn{2}{|c|}{ First order } & \multicolumn{2}{|c|}{ Second order } & \multicolumn{2}{|c|}{ Intraparticle diffusion } \\
\hline & $\mathrm{k}_{1}$ & $r$ & $\mathrm{k}_{2}$ & $r$ & $k_{i}$ & $r$ \\
\hline $\mathrm{C}_{0}=25 \mathrm{ppm}$ & 0.0241 & 0.997 & 0.0023 & 0.989 & 0.137 & 0.997 \\
\hline $\mathrm{C}_{0}=20 \mathrm{ppm}$ & 0.0297 & 0.995 & 0.0042 & 0.991 & 0.122 & 0.990 \\
\hline $\mathrm{C}_{0}=15 \mathrm{ppm}$ & 0.0255 & 0.999 & 0.004 & 0.974 & 0.0852 & 0.997 \\
\hline $\mathrm{C}_{0}=10 \mathrm{ppm}$ & 0.0371 & 0.999 & 0.0134 & 0.966 & 0.0642 & 0.992 \\
\hline
\end{tabular}

$\left[\mathrm{k}_{1}\right]=\mathrm{min}^{-1},\left[\mathrm{k}_{2}\right]=\mathrm{min}^{-3} \mathrm{ppm}^{-1}$ and $\left[\mathrm{k}_{\mathrm{i}}\right]=\mathrm{mg} \mathrm{g}^{-1} \mathrm{~min}^{-1 / 2}$

Table 3. Rate constants and correlation coefficients from treatment of adsorption data to three kinetic models in different masses of GAC

\begin{tabular}{c|cccccc}
\hline \multirow{2}{*}{$\begin{array}{c}\text { Amount of } \\
\text { GAC }(\boldsymbol{g})\end{array}$} & \multicolumn{6}{|c}{ Kinetic model } \\
\cline { 2 - 7 } & \multicolumn{2}{|c|}{ First order } & \multicolumn{5}{c}{ Second order } & \multicolumn{1}{c}{ Intraparticle diffusion } \\
& $\mathrm{k}_{1}$ & $\mathrm{r}$ & $\mathrm{k}_{2}$ & $\mathrm{r}$ & $\mathrm{k}_{\mathrm{i}}$ & $\mathrm{r}$ \\
\hline $\mathrm{m}=3$ & 0.0419 & 0.93 & 0.0165 & 0.998 & 0.0313 & 0.856 \\
$\mathrm{~m}=1.5$ & 0.0358 & 0.994 & 0.0066 & 0.987 & 0.0803 & 0.987 \\
$\mathrm{~m}=1$ & 0.0297 & 0.995 & 0.0042 & 0.991 & 0.1216 & 0.99 \\
$\mathrm{~m}=0.5$ & 0.0063 & 0.997 & 0.0004 & 0.993 & 0.0931 & 0.98 \\
\hline$\left[\mathrm{k}_{1}\right]=\mathrm{min}^{-1},\left[\mathrm{k}_{2}\right]=\mathrm{min}^{-4} \mathrm{ppm}^{-1}$ and $\left[\mathrm{k}_{\mathrm{i}}\right]=\mathrm{mg} \mathrm{g}^{-1} \mathrm{~min}^{-1 / 2}$
\end{tabular}

Table 4. Rate constants and correlation coefficients from treatment of adsorption data to three kinetic models for different $\mathrm{pH}$ values

\begin{tabular}{|c|c|c|c|c|c|c|}
\hline \multirow{3}{*}{$\begin{array}{c}p H \\
\text { values }\end{array}$} & \multicolumn{6}{|c|}{ Kinetic model } \\
\hline & \multicolumn{2}{|c|}{ First order } & \multicolumn{2}{|c|}{ Second order } & \multicolumn{2}{|c|}{ Intraparticle diffusion } \\
\hline & $\mathrm{k}_{1}$ & $r$ & $\mathrm{k}_{2}$ & r & $\mathrm{k}_{\mathrm{i}}$ & r \\
\hline $\mathrm{pH}=8$ & 0.0204 & 0.99 & 0.0023 & 0.998 & 0.0949 & 0.995 \\
\hline $\mathrm{pH}=7$ & 0.0297 & 0.995 & 0.0042 & 0.991 & 0.1216 & 0.99 \\
\hline $\mathrm{pH}=5$ & 0.0074 & 0.997 & 0.0005 & 0.997 & 0.0536 & 0.995 \\
\hline $\mathrm{pH}=2$ & 0.0072 & 0.99 & 0.0005 & 0.997 & 0.0522 & 0.999 \\
\hline
\end{tabular}

$\left[\mathrm{k}_{1}\right]=\mathrm{min}^{-1},\left[\mathrm{k}_{2}\right]=\mathrm{min}^{-5} \mathrm{ppm}^{-1}$ and $\left[\mathrm{k}_{\mathrm{i}}\right]=\mathrm{mg} \mathrm{g}^{-1} \mathrm{~min}^{-1 / 2}$

\subsection{Adsorption isotherms of Basic yellow 2}

The calculated constants of linear and non-linear isotherm models for BY2 adsorption onto GAC and their corresponding correlation coefficients are shown in Tables 5 and 6.

Table 5: Linear isotherms constants for BY2 adsorption onto GAC

\begin{tabular}{lcccc}
\hline & $\mathrm{q}_{\mathrm{m}}$ & $\mathrm{b}$ & $\mathrm{R}_{\mathrm{L}}$ & $\mathrm{r}$ \\
\hline Langmuir 1 & 598.8 & 0.304 & 0.0159 & 0.994 \\
Langmuir 2 & 98.45 & 0.271 & 0.0108 & 0.949 \\
\hline & & $\mathrm{K}_{\mathrm{f}}$ & $1 / \mathrm{n}$ & $\mathrm{r}$ \\
\hline Freundlich & & 149.99 & 0.441 & 0.946 \\
\hline BET & & $\mathrm{q}_{\mathrm{m}}$ & $\mathrm{K}_{\mathrm{b}}$ & $\mathrm{r}$ \\
\hline & & 499.32 & 83.44 & 0.993
\end{tabular}


Table 6. Nonlinear isotherms constants for BY2 adsorption onto GAC

\begin{tabular}{|c|c|c|c|c|c|}
\hline & $\mathrm{q}_{\mathrm{m}}$ & $\mathrm{b}$ & $R_{L}$ & \multirow{2}{*}{\multicolumn{2}{|c|}{$\frac{r}{0.964}$}} \\
\hline \multirow[t]{2}{*}{ Langmuir } & 632.28 & 0.277 & 0.0107 & & \\
\hline & \multicolumn{2}{|l|}{$K_{f}$} & $1 / n$ & \multicolumn{2}{|c|}{$r$} \\
\hline \multirow[t]{2}{*}{ Freundlich } & 182.37 & & 0.348 & \multicolumn{2}{|c|}{0.906} \\
\hline & $q_{m}$ & & $K_{b}$ & & \\
\hline \multirow[t]{2}{*}{ BET } & $5.75^{*} 10^{4}$ & & 0.083 & \multicolumn{2}{|c|}{0.534} \\
\hline & g & & A & B & $r$ \\
\hline Redlich-Pe & 1.63 & & 103.2 & 0.02 & 0.989 \\
\hline
\end{tabular}

It is observed, from Table 5, that type 1 Langmuir isotherm is the best-fitting linear model and from table 6 , it is observed that the Redlich-Peterson non-linear equation is the best-fitting isotherm among non-linear equations. Figures 6 and 7 show the experimental equilibrium data versus calculated ones for the adsorption of BY2 onto granular activated carbon, resulted from linear and nonlinear isotherm models, respectively.

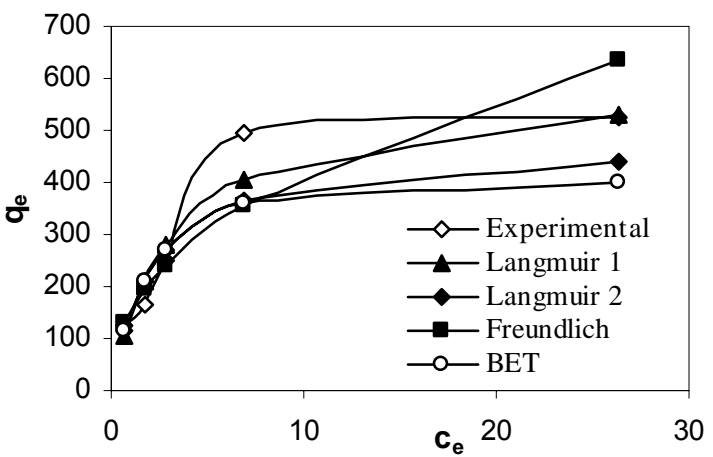

Figure 6. Experimental equilibrium data versus calculated ones for the adsorption of BY2 onto granular activated carbon resulted from linear isotherm models

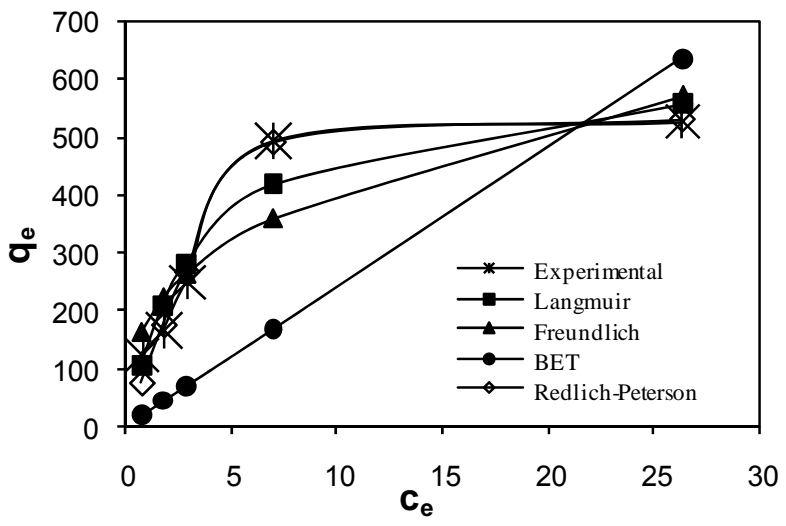

Figure 7. Experimental equilibrium data versus calculated ones for the adsorption of BY2 onto granular activated carbon resulted from nonlinear isotherm models

\section{CONCLUSION}

The adsorption of BY2 onto GAC could be followed by an on-line spectrophotometric analysis system. The adsorption of BY2 on GAC was dependent on initial dye concentration, adsorbent dosage, initial $\mathrm{pH}$ and temperature. The adsorption processes were found to follow different kinetic models over a period of $60 \mathrm{~min}$. Also type 1 linear Langmuir isotherm and non-linear RedlichPeterson isotherm seem to be the best-fitting models for the equilibrium experimental results.

\section{ACKNOWLEDGEMENT}

The authors would like to express their gratitude to the University of Tabriz for financial and other supports.

\section{REFERENCES}

Allen S.J. and Koumanova B. (2005), Decolourization of water/wastewater using adsorption (Review), Journal of the University of Chemical Technology and Metallurgy, 40, 175-192.

Alley E.R. (2000), Water Quality Control Handbook, McGraw Hill, New York.

Ayranci E. and Hoda N. (2004), Studies on removal of metribuzin, bromacil, 2,4-D and atrazine from water by adsorption on high area carbon cloth, Journal of Hazardous Materials, B 112, 163-168.

Ayranci E. and Hoda N. (2005), Adsorption kinetics and isotherms of pesticides onto activated carboncloth, Chemosphere, 60, 1600-1607. 
Benefield L.D., Judkins J.F. and Weand B.L. (1982), Process Chemistry for Water and Wastewater Treatment, Prentice-Hall Inc., Englewood Cliffs, NJ. 191-210.

Daneshvar N., Salari D. and Aber S. (2002), Chromium adsorption and $\mathrm{Cr}$ (VI) reduction to trivalent chromium in aqueous solutions by soya cake, Journal of Hazardous Materials B, 94, 49-61.

Daneshvar N., Aber S., Khani A. and Khataee A.R. (2007), Study of imidaclopride removal from aqueous solution by adsorption onto granular activated carbon using an on-line spectrophotometric analysis system, Journal of Hazardous Materials, 144, 47-51.

Eren Z. and Acar F.N. (2006), Adsorption of Reactive Black 5 from aqueous solution: equilibrium and kinetic studies, Desalination, 194, 1-10.

IARC (1987), Monographs on the Evaluation of Carcinogenic Risk to Humans, Supplement 7: Overall Evaluations of Carcinogenicity: an Updating of IARC Monographs, vol. 1, International Agency for Research on Cancer, France, Lyon.

Karagozoglu B., M. Tasdemir M., Demirbas E. and Kobya M. (2007), The adsorption of basic dye (Astrazon Blue FGRL) from aqueous solutions onto sepiolite, fly ash and apricot shell activated carbon: Kinetic and equilibrium studies, Journal of Hazardous Materials, 147, 297-306.

Mall I.D., Srivastava V.C. and Agarwal N.K. (2007), Adsorptive removal of Auramine-O: Kinetic and equilibrium study, Journal of Hazardous Materials, 143, 386-395.

Martelli A., Campart G.B., Canonero R., Carrozzino R., Mattioli F., Robbiano L. and Cavanna M. (1998), Evaluation of auramine genotoxicity in primary rat and human hepatocytes and in the intact rat, Mutation Research, 414, 37-47.

Matsumura Y.Y., Xu X. and Antal M.J. (1997), Gasification characteristics of an activated carbon in supercritical water, Carbon, 35, 819-824.

Mustafa S., Dilara B., Nargis K., Naeem A. and Shahida P. (2002), Surface properties of the mixed oxides of iron and silica, Physicochemical Engineering Aspects, 205, 273-282.

Namasivayam C. and Yamuna R.T. (1995), Adsorption of chromium (VI) by a low-cost adsorbent: biogas residual slurry, Chemosphere, 30, 561-578.

Nassar M.M. and Magdy Y.H. (1997), Removal of different basic dyes from aqueous solutions by adsorption on palm-fruit bunch particles, Chemical Engineering Journal, 66, 223-226.

Sanghi R. and Bhattacharya B. (2002), Review on decolorization of aqueous dye solutions by low cost adsorbents, Coloration Technology, 118, 256-269.

Woodard F. (2001), Industrial Waste Treatment Handbook, Butterworth-Heinemann Inc, Woburn, USA, 260-261. 